\title{
KESIAPAN PEMERINTAH DAERAH DALAM PENERAPAN STANDAR AKUNTANSI PEMERINTAHAN BERBASIS AKRUAL (Studi Kasus Pada Badan Keuangan Provinsi Gorontalo)
}

\author{
Saprudin \\ Universitas Gorontalo(UG) \\ Email: saprudin545@gmail.com
}

\begin{abstract}
Abstrak
Permasalahan Sumber Daya Manusia yang ada di Badan Keuangan Provinsi Gorontalo memiliki latar belakang pendidikan yang tidak sesuai dengan jabatan yang mereka pegang. Memiliki keterampilan yang kurang memadai. Teknologi informasi yang dimiliki Badan Keuangan Provinsi Gorontalo sudah memiliki perangkat Komputer yang lengkap, akan tetapi masih kurangnya pemeliharaan peralatan.

Tujuan penelitian ini adalah untuk mengetahui Untuk mengetahui Sumber daya manusia dan teknologi informasi berpengaruh positif terhadap Penerapan Standar Akuntansi Pemerintah Berbasis Akrual Pada Badan Keuangan Provinsi Gorontalo. Hasil penelitian menunjukan bahwa sumber daya manusia berpengaruh positif dan signifikan terhadap penerapan standar akuntansi pemerintahan berbasis akrual, selain itu untuk teknologi informasi berpengaruh positif dan signifikan terhadap penerapan standar akuntansi pemerintahan berbasis akrual.

Hasil uji koefisien determinasi menunjukan bahwa penerapan tandar akuntansi pemerintahan berbasis akrual pada Badan Keuangan Provinsi Gorontalo dipengaruhi oleh sumber daya manusia dan teknologi informasi sebesar $28,9 \%$ dan sisanya $71,1 \%$ dipengaruhi variabel lain yang belum diteliti dalam penelitian ini antara lain komitmen organisasi dan saranan prasarana
\end{abstract}

Kata Kunci: Sumber Daya Manusia, Teknologi Informasi, Penerapan Standar Akuntansi Pemerintahan Berbasis Akrual.

\begin{abstract}
The problems of human resources is Gorontalo provincial financial institution have educational background that is not in accordance with the position they hold. Having inadequate skills, information technology owned by Gorontalo Provincial financial institution already has complete device, but skill lack of equipment maintenance.

The purpose of this study is to know To know human resources and information technology positively affect the Application of Accounting Standards Based Government Accrual At The Financial Agency Gorontalo Province. The results showed that human resources have a positive and significant impact on the implementation of accounting standards based on accrual government, in addition to information technology has a positive and significant impact on the implementation of accounting standards based on accrual government.

The result of determination coefficient thes shows that the implementation of accrual govement based accounting standards at Gorontalo Provincial Finance Board affected by human resources and information technology $28,9 \%$ and the rest $71,1 \%$ influenced other variables that have not been studied in this study include organizational commitment and infrastructure facilities.
\end{abstract}

Keywords: Human Resources, Information Technology, Application Of Accrual Based Government Accounting Standards. 


\section{PENDAHULUAN}

Pemerintah Indonesia terus melakukan berbagai usaha untuk meningkatkan transparansi dan akuntabilitas pengelolaan keuangan negara dalam rangka menciptakan tata kelola yang baik (good governance). Untuk meningkatkan transparansi dan akuntabilitas pengelolaan keuangan negara salah satunya adalah dengan melakukan pengembangan kebijakan akuntansi pemerintah berupa standar akuntansi pemerintahan (SAP) yang bertujuan untuk memberikan pedoman pokok dalam penyusunan dan penyajian laporan keuangan pemerintah baik pemerintah pusat maupun pemerintah daerah.

Disahkannya

Peraturan Pemerintah (PP) Nomor 71 Tahun 2010 tentang Standar Akuntansi Pemerintahan (SAP) dan Peraturan Menteri Dalam Negeri (Permendagri) Nomor 64 Tahun 2013 tentang Penerapan Standar Akuntansi Pemerintahan Berbasis Akrual Pada Pemerintah Daerah, pada Pasal 10 ayat (2) yang menyatakan penerapan SAP berbasis akrual pada pemerintah daerah paling lambat diterapkan tahun Anggaran 2015.

Peraturan Pemerintah Nomor 71 Tahun 2010 pasal 1 ayat (8) menyatakan bahwa Standar Akuntansi Pemerintahan Berbasis Akrual adalah Standar Akuntansi Pemerintahan yang mengakui pendapatan, beban, aset, utang, dan ekuitas dalam pelaporan finansial berbasis akrual, serta mengakui pendapatan, belanja, dan pembiayaan dalam pelaporan pelaksanaan anggaran berdasarkan basis yang ditetapkan dalam APBN/APBD.

Penerapan SAP berbasis akrual harus dilakukan secara hati-hati dengan persiapan yang matang dan terstruktur. Untuk mencapai hal ini ada beberapa hal yang harus disiapkan terkait dengan penerapan SAP berbasis akrual di daerah, yakni ketersediaan sumber daya manusia (SDM), teknologi informasi, infrastruktur, sistem informasi, dan pemerintah harus memiliki komitmen dan integritas yang tinggi untuk melaksanakan SAP berbasis akrual. Kesuksesan penerapan SAP berbasis akrual sangat diperlukan sehingga pemerintah dapat menghasilkan laporan keuangan yang lebih transparan dan lebih akuntabel. Untuk itu diperlukan faktor-faktor pendukung yang dapat mempengaruhi kesuksesan tersebut dan kerja sama dari berbagai pihak.

Salah satu faktor yang mempengaruhi keberhasilan penerapan SAP berbasis akrual adalah tersedianya SDM yang kompeten dan andal di bidang akuntansi. Oleh karena itu pemerintah pusat dan daerah perlu secara serius menyusun perencanaan dan penempatan sumber daya manusia di bidang akuntansi pemerintahan. Karena sumber daya manusia merupakan semua manusia yang terlibat di dalam suatu organisasi dalam mengupayakan terwujudnya tujuan organisasi tersebut.

Faktor lain yang tidak kalah penting adalah komitmen dari organisasi/instansi dalam hal ini yang berwenang dalam pengambilan keputusan adalah pimpinan organisasi itu sendiri. Dukungan yang kuat dari pimpinan merupakan kunci keberhasilan dari suatu perubahan. Salah satu penyebab kelemahan penyusunan Laporan Keuangan pada beberapa Kementerian/Lembaga adalah lemahnya komitmen pimpinan satuan kerja khususnya BPKD (Badan Pemeriksa Keuangan Daerah) penerima dana Dekonsentrasi/Tugas Pembantuan.

Faktor selanjutanya adalah sarana pendukung berupa teknologi informasi yang terdiri dari hardware dan software yang memadai dalam pelaksanaan SAP berbasis akrual. teknologi informasi selain sebagai teknologi komputer (hardware dan software) untuk pemrosesan dan penyimpanan informasi, juga berfungsi sebagai teknologi komunikasi untuk penyebaran informasi.

Kemudian Infrastruktur juga mengacu pada sistem fisik yang menyediakan transportasi, air, 
bangunan, dan fasilitas publik lain yang diperlukan untuk memenuhi kebutuhan dasar manusia secara ekonomi dan sosial. Infrastruktur dibuat sesuai permintaan se efisien mungkin yang dapat meningkatkan taraf hidup masyarakat luas. Selanjutnya Sistem informasi adalah salah satu alat untuk menyajikan informasi sedemikian rupa sehingga bermanfaat bagi penerimanya.

Badan Keuangan Provinsi Gorontalo merupakan Satuan Kerja Perangkat Daerah (SKPD) yang mengelola keuangan daerah baik pengelolaan pendapatan daerah maupun pengelolaan keuangan dan aset daerah. Dalam membiayai kegiatan dan pelaksanaan tugasnya memperoleh alokasi dana dari Anggaran Pendapatan Dan Belanja Daerah (APBD). Oleh karena itu, Pemerintah Daerah wajib menyusun laporan keuangan sebagai bentuk pertanggungjawaban atas pengelolaan anggaran daerah yang diperolehnya. Kesesuaian penyajian laporan keuangan dengan standar akuntansi pemerintahan menjadi dasar diberikannya opini atas laporan keuangan Badan Keuangan Provinsi Gorontalo.

Untuk Badan Keuangan Provinsi Gorontalo dalam hal penerapan SAP berbasis akrual masih terbilang hal baru. Hal ini dibuktikan SAP berbasis akrual ini baru diterapkan pada tahun 2015. Tentunya hal ini akan berdampak pada kesiapan para pegawai yang ada di Badan Keuangan Provinsi Gorontalo.

Terkait dengan penerapan basis akrual sendiri, Pemerintah Daerah tidak perlu melakukan kesiapan lagi, tapi seharusnya peraturan ini sudah berjalan dari sejak diterbitkan peraturan tersebut dari tahun 2010, dengan memperhatikan mulai dari Kualitas Sumber Daya Manusia seperti tingkat pendidikan staf, latar belakang pendidikan pimpinan dan dibutuhkan lebih banyak pelatihan untuk meningkatkan kompetensi sumber daya manusia khususnya bidang akuntansi pemerintah. Selain itu, meningkatkan kualitas Teknologi Informasi yang juga berfungsi membantu Badan Keuangan
Provinsi Gorontalo dalam melaksanakan tugas seperti tersedianya komputer dan software yang berkaitan dengan kebutuhan dalam penerapan SAP, Persiapan tersebut dilakukan agar siap dan dapat mengatasi berbagai kendala dalam penerapan basis akrual.

Sumber Daya Manusia yang ada di Badan Keuangan Provinsi Gorontalo memiliki latar belakang pendidikan yang tidak sesuai dengan jabatan yang mereka pegang. Memiliki keterampilan yang kurang memadai. Teknologi informasi yang dimiliki Badan Keuangan Provinsi Gorontalo sudah memiliki perangkat Komputer yang lengkap, akan tetapi masih kurangnya pemeliharaan peralatan.

Darise ( 2008:4 ) mengemukakan Standar Akuntansi Pemerintahan meruapakan persyaratan yang mempunyai kekuatan hukum dalam upaya meningkatkan kualitas laporan keuangan pemerintah di Indonesia. Standar Akuntansi Pemerintahan (SAP) adalah prinsip-prinsip akuntansi yang diterapkan dalam menyusun dan menyajikan laporan keuangan pemerintah dalam rangka transparansi dan akuntabilitas penyelenggaraan akuntansi pemerintah, serta peningkatan kualitas laporan keuangan pemerintah pusat (LKPP) dan laporan keuangan pemerintah daerah (LKPD).

Menurut Abdul dan Khusufi ( 2012:224 ) Standar Akuntansi Pemerintahan merupakan regulasi yang dibuat oleh pemerintah untuk mengatur sistem pelaporan keuangan dan akuntansi pemerintah, yang terdiri atas pemerintah pusat, pemerintah daerah, masing-masing kementrian Negara atau lembaga di lingkungan pemerintah pusat, dan satuan organisasi di lingkungan pusat/daerah yang diwajibkan oleh peraturan perundangundangan untuk menyusun laporan keuangan. Dapat disimpulkan bahwa Standar Akuntansi Pemerintahan adalah suatu konsep dan persyaratan yang mempunyai kekuatan hukum dalam upaya meningkatkan kualitas laporan keuangan pemerintah di Indonesia. Dari 
beberapa pengertian diatas dapat dinyatakan bahwa Standar Akuntansi Pemerintahan meruapakan pedoman wajib dalam menyusun dan menyajikan laporan keuangan dalam pemerintahan, baik pemerintah pusat maupun pemerintah daerah dalam rangka mencapai transparansi dan akuntabilitas. Standar Akuntansi Pemerintahan dapat menjadi pedoman untuk menyatukan persepsi antara penyusun, pengguna dan auditor.

Peraturan Menteri Dalam Negeri No. 64 Tahun 2013 Pasal 1 ayat (10) menjelaskan bahwa Basis akrual adalah basis akuntansi yang mengakui pengaruh transaksi dan peristiwa pada saat transaksi dan peristiwa itu terjadi, tanpa memperhatikan saat kas atau setara kas diterima atau dibayar.

Menurut Darise ( 2008:39 ). Basis akrual adalah dasar akuntansi yang mengakui transaksi dan peristiwa lainnya pada saat transaksi dan peristiwa itu terjadi (dan bukan hanya pada saat kas atau setara kas diterima atau dibayar) oleh karena itu, transaksitransaksi dan peristiwa-peristiwa dicatat dalam catatan akuntansi dan diakui dalam laporan keuangan pada periode terjadinya. Basis akrual mampu menghasilkan informasi yang tidak dapat dipenuhi oleh basis kas. Tujuan pelaporan tersebut adalah tujuan manajerial dan pengawasan.

Halim dan Kusufi ( 2012: 53 ) menyimpulkan bahwa basis akrual mampu memenuhi tujuan pelaporan yang tidak dapat dipenuhi oleh basis kas, tujuan pelaporan tersebut adalah tujuan manajerial dan pengawasan. Beberapa masalah aplikasi basis akrual yang dapat diidentifikasikan antara lain (Bastian, 2010: 120) :

1. Penentuan pos dan besaran transaksi yang dicatat dalam jurnal dilakukan oleh individu yang mencatat.

2. Relevansi akuntansi akrual menjadi terbatas ketika dikaitkan dengan nilai historis dan inflasi.

3. Dalam pembandingan dengan basis kas, penyesuaian akrual membutuhkan prosedur administrasi yang lebih rumit, sehingga biaya admnistrasi menjadi lebih mahal.

4. Peluang manipulasi keuangan yang sulit dikendalikan.

Peraturan Pemerintah Nomor 71 Tahun 2010 pasal 1 ayat (8) menyatakan bahwa Standar akuntansi pemerintahan berbasis akrual adalah standar akuntansi pemerintahan yang mengakui pendapatan, beban, aset, utang, dan ekuitas dalam pelaporan finansial berbasis akrual, serta mengakui pendapatan, belanja, dan pembiayaan dalam pelaporan pelaksanaan anggaran berdasarkan basis yang ditetapkan dalam APBN/APBD (Halim dan Kusufi, 2012 : 217).

Secara sederhana, penerapan akuntansi berbasis akrual ditujukan mengatasi ketidak cukupan basis kas untuk memberikan data yang lebih akurat. Tujuannya untuk memberikan informasi yang lebih transparan mengenai biaya pemerintah dan meningkatkan kualitas pengambilan keputusan di dalam pemerintah dengan menggunakan informasi yang diperluas, tidak sekedar basis kas. Tujuan kuncinya adalah untuk meminta pertanggungjawaban para pengelola dari sisi keluaran dan hasil serta pada saat yang sama mengendalikan atas masukan. Komponen Laporan Keuangan meliputi Laporan Realisasi Anggaran (LRA), Laporan Perubahan Saldo Anggaran Lebih (SAL), Neraca, Laporan Operasional (LO), Laporan Arus Kas (LAK), Laporan Perubahan Ekuitas (LPE)( Tanjung, 2014 : 6 )

Menurut Rachmawati (2008:1) Sumber daya manusia kini makin brperan besar bagi kesuksesan suatu organisasi. Banyak organisasi menyadari bahwa unsur manusia dalam suatu organisasi dapat memberikan keunggulan bersaing. Mereka membuat sasaran, strategi, inovasi, dan mencapai tujuan organisasi. Oleh karena itu sumber daya manusia merupakan salah satu unsur yang paling vital bagi organisasi. Terdapat dua alasan dalam hal ini. Pertama, sumber daya manusia memengaruhi efisiensi dan 
efektivitas organisasi- sumber daya manusia merancang dan memproduksi barang dan jasa, mengawasi kualitas, memasarkan produk, mengalokasikan sumber daya finansial, serta menentukan seluruh tujuan dan strategi organisasi. Kedua, sumber daya manusia merupakan pengeluaran utama organisasi dalam menjalankan bisnis.

Menurut Sutrisno (2014:3), Sumber daya manusia adalah merupakan satusatunya sumber daya yang memiliki akal perasaan, keinginan, keterampilan, pengetahuan, dorongan, daya dan karya (rasio, rasa dan karsa). Semua potensi Sumber Daya Manusia tersebut berpengaruh terhadap upaya organisasi dalam mencapai tujuan.

Menurut Tjiptoherijanto ( 2008122 ), untuk menilai kapasitas dan kualitas sumber daya manusia dalam melaksanakan suatu fungsi, termasuk akuntansi, dapat dilihat dari level of responsibility dan kompetensi sumber daya tersebut. Tanggung jawab dapat dilihat dalam deskripsi jabatan. Deskripsi jabatan merupakan dasar untuk melaksanakan tugas dengan baik. Tanpa adanya deskripsi jabatan yang jelas, sumber daya tersebut tidak dapat melaksanakan tugasnya dengan baik. Sedangkan kompetensi dapat dilihat dari latar belakang pendidikan, pelatihan pelatihan yang pernah diikuti, dan dari keterampilan yang dinyatakan dalam pelaksanaan tugas.

Sumber daya manusia adalah semua manusia yang terlibat dalam pembuatan laporan keuangan daerah, SDM yang berkualitas harus mampu menghasilkan laporan keuangan sesuai dengan aturan yang berlaku. Kegagalan sumber daya manusia Pemerintah Daerah dalam memahami dan menerapkan logika akuntansi akan berdampak pada kekeliruan laporan keuangan yang dibuat dan ketidaksesuaian laporan dengan standar yang ditetapkan pemerintah (Warisno dalam Putri,2010).

Teknologi informasi meliputi komputer, perangkat lunak (software), database (jaringan intrnet) dan jenis lannya yang berhubungan dengan teknologi. (Wilkinson et al.,2010 : 25). Teknologi informasi selain sebagai teknologi komputer (hardware dan software) untuk pemrosesan dan penyimpanan informasi, juga berfungsi sebagai teknologi komunikasi untuk penyebaran informasi.

Kualitas suatu informasi tergantung dari beberapa hal yaitu (Mukhtar, 2002: 4):

a. Akurat

Akurat berarti informasi harus bebas dari kesalahan-kesalahan dan tidak menyesatkan. Informasi harus akurat karena dari sumber informasi sampai ke penerima informasi kemungkinan banyak terjadi gangguan yang dapat merubah atau merusak informasi tersebut.

b. Tepat waktu

Ini berarti informasi yang datang pada penerima tidak boleh terlambat. Jika pengambilan keputusan terlambat, maka dapat berakibat fatal untuk organisasi.

c. Relevan

Relevan berarti informasi tersebut harus mempunyai manfaat untuk pemakainya.

d. Lengkap

Informasi yang disajikan termasuk di dalamnya semua data-data yang relevan dan tidak mengabaikan kepentingan yang diharapkan oleh pembuat keputusan.

e. Dapat dimengerti

Informasi yang disajikan hendaknya dalam bentuk yang mudah dimengerti oleh pembuat keputusan. Nilai dari informasi ditentukan oleh dua hal yaitu manfaat dan biaya untuk mendapatkannya. Suatu informasi dikatakan bernilai bila manfaatnya lebih efektif dibandingkan dengan biaya untuk mendapatkannya.

Damanik (2011) dengan judul "Faktor-faktor Yang Menjadi Kendala Dalam Penerapan Standar Akuntansi Pemerintahan (SAP) Pada Pemerintah Kota Binjai" dengan tujuan untuk mengetahui faktor-faktor yang menjadi kendala dalam penerapan standar akuntansi pemerintahan (SAP) pada pemerintah Kota Binjai. Jenis penelitian 
yang dilakukan adalah penelitian asosiatif kausal yaitu penelitian yang bertujuan untuk mengetahui hubungan antara dua variabel atau lebih. Hasil analisis regresi secara keseluruhan menunjukkan $R$ sebesar 0.604 yang berarti bahwa korelasi/hubungan antara sumber daya manusia, komitmen dan perangkat pendukung dengan kendala penerapan SAP mempunyai hubungan yang kuat sebesar $60.4 \%$.

\section{METODE}

Dalam penelitian ini populasinya adalah pegawai bagian keuangan yang terlibat langsung dalam penyusunan laporan keuangan dan bagian Staf Administrasi berjumlah 60 orang. Instrumen pengumpulan data menggunakan penyebaran koesioner, sedangkan skala yang digunakan adalah skala Liket. Pada masing-masing Skala Likert tersebut diberikan sejumlah bobot atau nilai. Berikut adalah alternativealternatif jawaban berdasarkan skala likert pembobotannya dalam penelitian ini

Tabel 1. Pengukuran Skala Likert

\begin{tabular}{ll}
\hline Jawaban Responden & Skor \\
\hline Sangat Setuju & 5 \\
Setuju & 4 \\
Kurang Setuju & 3 \\
Tidak Setuju & 2 \\
Sangat Tidak Setuju & 1 \\
\hline
\end{tabular}

Data yang terkumpul kemudian di analisis menggunakan program SPSS versi 21. Metode analisis data menggunakan regresi linier berganda,dengan rumus regresi berganda.

$Y=a+b_{1} X_{1}+b_{2} X_{2}$

Keterangan :

$\mathrm{Y} \quad=$ Penerapan Standar Akuntansi

Pemerintahan Berbasis Akrual

a $=$ Konstanta

$b_{1}-b_{2}=$ Koefisien regresi variabel bebas
$\mathrm{X}_{1} \quad=$ Kualitas SDM

$\mathrm{X}_{2}=$ Kualitas Teknologi Informasi

\section{HASIL DAN PEMBAHASAN}

Dalam penelitian ini, peneliti menyebarkan kuesioner ke 60 responden. Untuk memperoleh gambaran tentang karakteristik responden yang akan diteliti, dilakukan pengolahan data melalui perhitungan statistik deskriptif.

Tabel 2. Jenis Kelamin Responden

\begin{tabular}{lll}
\hline Jenis Kelamin & Frekuensi & Persen \\
\hline Laki-laki & 27 & 45,0 \\
Perempuan & 33 & 55,0 \\
Total & 60 & 100,0 \\
\hline
\end{tabular}

Sumber data olahan

Dari tabel diatas, menunjukan bahwa jumlah responden laki-laki sebanyak 27 orang atau sekitar 45,0\% lebih kecil dibandingkan jumlah responden perempuan yang berjumlah 33 orang atau sekitar $55.0 \%$
Hasil penilaian responden pada Badan Keuangan Provinsi Gorontalo terbesar menjawab setuju sebanyak 33 orang, 26 orang menjawab sangat setuju dan 1 orang ,menjawab kurang setuju. Hal ini terlihat dari banyaknya responden yang 
menjawab setuju bahwa pada Badan keuangan provinsi gorontalo Pegawainya paham dan bisa menyediakan informasi mengenai sumber, alokasi, dan penggunaan sumber daya ekonomi. Berdasarkan hasil wawancara dengan salah satu Staf Bidang Akuntansi pada tanggal 26 April 2017 Pada Badan Keuangan Provinsi Gorontalo, menjelaskan bahwa Pegawai Badan Keuangan paham dan bisa menyediakan informasi mengenai sumber, alokasi dan penggunaan sumber daya ekonomi. Hal ini dibuktikan dengan telah disajikannya laporan keuangan yang sudah WTP (Wajar Tanpa Pengecualian) pada Badan Keuangan Provinsi Gorontalo

Tabel 3. Hasil Pengujian Regresi Berganda

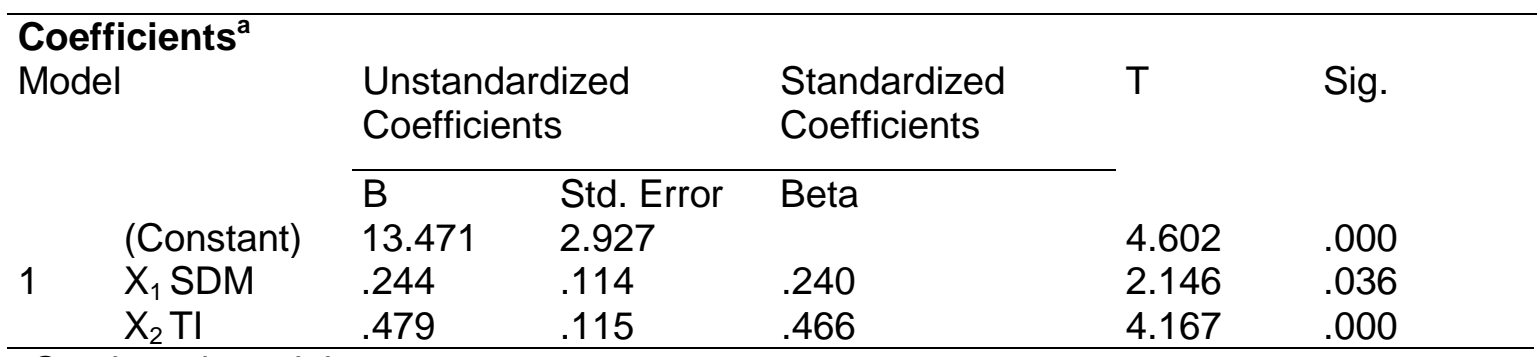

Sumber: data olahan

$Y=13.471+0,244 X_{1}+0,479 X_{2}$

Dalam persamaan regresi diatas, konstanta $(\beta 0)$ adalah sebesar 13.471 hal ini berarti jika tidak ada perubahan variabel Sumber Daya Manusia (X1) dan Teknologi Informasi (X2) yang mempengaruhi, Penerapan SAP Basis Akrual yang terjadi pada provinsi gorontalo sebesar 13.471. sedangkan hasil uji regresi berganda untuk variabel independen dapat dijelaskan sebagai berikut :

1. Nilai koefisien Sumber Daya Manusia (X1) sebesar 0,244 berpengaruh positif terhadap Penerapan SAP berbasis akrual (Y). Hal ini mengandung arti bahwa setiap kenaikan Sumber Daya Manusia satu satuan maka variabel Penerapan SAP basis akrual naik sebesar 0,244 dengan asumsi bahwa variabel independen yang lainnya tetap.

2. Nilai koefisien Teknologi Informasi (X2) sebesar 0,479 berpengaruh positif terhadap Penerapan SAP berbasis Akrual (Y). Hal ini mengandung arti bahwa setiap kenaikan Teknologi Informasi satu satuan maka variabel Penerapan SAP berbasis akrual naik sebesar 0,479 dengan asumsi bahwa variabel independen yang lainnya tetap.

Tabel 4. Uji F

\begin{tabular}{|c|c|c|c|c|c|c|}
\hline \multicolumn{7}{|c|}{ ANOVA $^{a}$} \\
\hline \multicolumn{2}{|l|}{ Model } & Sum & of $\mathrm{df}$ & Mean & $\mathrm{F}$ & Sig. \\
\hline & Rearession & 37907 & 2 & 18953 & 11607 & $000^{b}$ \\
\hline \multirow[t]{2}{*}{1} & Residual & 93.077 & 57 & 1.633 & & \\
\hline & Total & 130.983 & 59 & & & \\
\hline \multicolumn{7}{|c|}{ a. Dependent Variable: TOYALY } \\
\hline \multicolumn{7}{|c|}{ b. Predictors: (Constant), TOTALX2, TOTALX1 } \\
\hline
\end{tabular}

Sumber: data olahan 
Tabel 5. Uji ANOVA

\begin{tabular}{|c|c|c|c|c|c|c|}
\hline \multirow{3}{*}{ Model } & \multicolumn{5}{|c|}{ Coefficients $^{\mathrm{a}}$} & \multirow{3}{*}{ Sig. } \\
\hline & & \multirow{2}{*}{\multicolumn{2}{|c|}{$\begin{array}{l}\text { Unstandardized } \\
\text { Coefficients }\end{array}$}} & \multirow{2}{*}{$\begin{array}{l}\text { Standardized } \\
\text { Coefficients } \\
\text { Beta }\end{array}$} & \multirow[t]{2}{*}{$\mathrm{T}$} & \\
\hline & & & & & & \\
\hline & $\begin{array}{l}\text { (Consta } \\
\text { nt) }\end{array}$ & 13.471 & 2.927 & & 4.602 & .000 \\
\hline 1 & $\begin{array}{l}\text { TOTALX } \\
1\end{array}$ & .244 & .114 & .240 & .200 & .036 \\
\hline a. Dep & $\begin{array}{l}\text { TOTALX } \\
2 \\
\text { pendent V }\end{array}$ & $\begin{array}{l}.479 \\
\text { /ariable: TOY }\end{array}$ & .115 & .466 & 4.167 & .000 \\
\hline
\end{tabular}

Berdasarkan tabel diatas hasil uji ANOVA (Analysis of variance) diperoleh nilai $F$ hitung (11.607) sedangkan nilai $F$ tabel $(3,156)$ yang artinya nilai $F$ hitung lebih besar dari nilai $F$ tabel sehingga terbukti bahwa variabel $X_{1}$ dan $X_{2}$ secara bersama-sama berpengaruh signifikan terhadap variabel $\mathrm{Y}$ dimana $\mathrm{H}_{0}$ ditolak dan $\mathrm{H}_{3}$ diterima yang berarti terdapat pengaruh antara sumber daya manusia dan teknologi informasi secara bersama-sama terhadap penerapan SAP basis akrual $(Y)$. Selanjutnya dilihat dari hasil nilai signifikan yang diperoleh sebesar $(0,000)$ lebih kecil dari nilai $(0,05)$ artinya model regresi yang digunakan layak uji, hal ini membuktikan semakin baik sumber daya manusia dan teknologi informasi secara bersama-sama maka akan meningkatkan penerapan SAP basis akrual.

Dari tabel diatas diketahui hasil dari nilai $t$ hitung untuk masing-masing variable independen $(X)$ terhadap dependen $(Y)$ adalah sebagai berikut :

1. Sumber Daya Manusia berpengaruh positif dan signifikan terhada Penerapan SAP basis akrual secara parsial hal ini dibuktikan dengan nilai t hitung $(2,146)>$ nilai dari t tabel $(1,672)$ dan nilai signifikan $0,036<0,05$ maka $\mathrm{H} 1$ diterima.

2. Teknologi Informasi berpengaruh positif dan signifikan terhadap Penerapan SAP basis akrual secara parsial. Hal ini dibuktikan dengan nilai t hitung $(4,167)>$ nilai dari t tabel $(1,672)$ dan nilai signifikan $0,000<0,05$ maka $\mathrm{H} 1$ diterima.

Tabel 6. Uji Korelasi

\begin{tabular}{|c|c|c|c|c|}
\hline \multicolumn{5}{|c|}{ Model Summary ${ }^{b}$} \\
\hline Model $\mathrm{R}$ & R Square & $\begin{array}{l}\text { Adjusted } \\
\text { Square }\end{array}$ & $\begin{array}{c}\text { R Std. Error of } \\
\text { the Estimate }\end{array}$ & $\begin{array}{l}\text { Durbin- } \\
\text { Watson }\end{array}$ \\
\hline $.538^{\mathrm{a}}$ & .289 & .264 & 1.278 & 2.020 \\
\hline \multicolumn{5}{|c|}{ a. Predictors: (Constant), TOTALX2, TOTALX1 } \\
\hline
\end{tabular}

Berdasarkan tabel diatas diperoleh nilai $R$ (koefisien korelasi) sebesar 0,538. Hal ini menunjukan bahwa terjadi hubungan antara sumber daya manusia dan teknologi informasi terhadap penerapan SAP basis akrual sebesar $53,8 \%$.
$R^{2}$ (Koefisien determinasi) adalah suatu nilai yang menunjukan kemampuan variabel bebas menjelaskan variabel terikat, dalam penelitian ini nilai $R^{2}$ yang diperoleh sebesar 0,289 yang menunjukan bahwa penerapan SAP basis akrual pada 
Badan Keuangan Provinsi Gorontalo dipengaruhi oleh sumber daya manusia dan teknologi informasi sebesar $28,9 \%$ dan sisanya $\left(1-R^{2}\right) \quad 1-0,289=0,711$ $(71,1 \%)$ dipengaruhi oleh variabel lain yang tidak diteliti dalam penelitian ini. Adapun variabel lain antara lain komitmen organisasi, dan sarana prasarana.

Berdasarkan uji parsial yang telah dilakukan antara sumber daya manusia sebagai (X1) terhadap penerapan SAP basis ( $\mathrm{Y}$ ) menunjukan bahwa $\mathrm{t}$ hitung sebesar 2.146 dengan nilai signifikan sebesar $(0,036<0,05)$ menunjukan bahwa variabel sumber daya manusia berpengaruh positif dan signifikan terhadap penerapan SAP basis akrual. Hasil uji hipotesis ini sama dengan hipotesis sebelumnya yang menunjukkan bahwa adanya pengaruh Sumber Daya Manusia terhadap Penerapan SAP Basis Akrual.

Untuk melihat besarnya pengaruh sumber daya manusia secara parsial terhadap penerapan SAP basis akrual dapat dihitung dari nilai koefisien regresi parsial pada Tabel 5.30 sebesar 0,244. Jadi secara parsial sumber daya manusia berpengaruh terhadap penerapan SAP basis akrual pada Badan Keuangan Provinsi Gorontalo sebesar $0,244^{2} x$ $100 \%=5,95 \%$. Dengan demikian Oleh sebab itu dapat disimpulkan bahwa semakin tinggi kualitas sumber daya manusia dalam pemahaman standar akuntansi pemerintahan berbasis akrual, maka semakin tinggi tingkat kesiapan penerapan standar akuntansi pemerintahan berbasis akrual pemerintah daerah Badan Keuangan Provinsi Gorontalo. Tingkat pendidikan memiliki pengaruh dalam melaksanakan pekerjaan khususnya di bidang akuntansi karena semakin tinggi tingkat pendidikan, semakin banyak ilmu pengetahuan yang dimiliki dan semakin luas wawasan serta semakin mudah dalam memahami pekerjaan yang dilakukan.

Pegawai pada pemerintah harus siap ditempatkan disegala bagian pekerjaan karena mutasi jabatan sangat sering dilakukan dalam pemerintah tidak terkecuali mutasi ke bagian akuntansi. Bagian akuntansi adalah bagian yang sangat penting dan sering dilakukan pemeriksaan baik oleh pihak intern maupun pihak ekstern. Hal ini berarti bagian bagian keuangan sangat memerlukan kemampuan dan ketelitian dalam bekerja.

Berdasarkan uji parsial yang telah dilakukan antara Teknologi Informasi (X2) terhadap Penerapan SAP Basis Akrual (Y) menunjukan bahwa t hitung sebesar 2,146 dengan nilai signifikan sebesar $(0,000<$ $0,05)$ menunjukan bahwa variabel teknologi informasi berpengaruh positif dan signifikan terhadap penerapan SAP basis akrual. Hasil uji hipotesis ini sama dengan hipotesis sebelumnya yang menunjukkan bahwa adanya pengaruh teknologi informasi terhadap penerapan SAP basis akrual.

Berdasarkan hasil uji simultan yang telah dilakukan antara Sumber Daya Manusia X1 dan Teknologi Informasi X2 terhadap Penerapan SAP Basis Akrual $Y$ menunjukan bahwa $f$ hitung sebesar 11.607 dengan nilai signifikan sebesar $0,000<0,05$ menunjukan bahwa variabel sumber daya manusia dan teknologi informasi berpengaruh positif dan signifikan terhadap penerapan SAP basis akrual. Hasil penelitian ini dapat menjawab hipotesis yang telah diajukan oleh peneliti sumber daya manusia dan teknologi informasi berpengaruh positif terhadap penerapan SAP basis akrual pada Badan Keuangan Provinsi Gorontalo. Hal tersebut juga ditunjukkan oleh nilai koefisien determinasi yang cukup tinggi, yaitu dengan nilai $R$ square sebesar 0 , 289. Yang memperlihatkan bahwa 28,9\% penerapan SAP basis akrual dipengaruhi oleh sumber daya manusia dan teknologi informasi. Sedangkan sisanya $71,1 \%$ dipengaruhi oleh variabel lain yang tidak ada dalam penelitian ini.

\section{SIMPULAN DAN SARAN}

Berdasarkan hasil analisa data yang telah diuraikan pada bab sebelumnya, maka dapat disampaikan sebagai berikut. 1). Berdasarkan 
pengujian secara parsial (Uji T), menunjukkan bahwa variabel sumber daya manusia (X1) berpengaruh positif dan signifikan terhadap penerapan SAP basis akrual $(Y)$, dan variabel teknologi informasi (X2) berpengaruh positif tetapi dan signifikan penerapan SAP basis akrual $(Y)$ pada Badan Keuangan Provinsi Gorontalo. 2). Berdasarkan pengujian secara simultan (Uji F), menunjukkan bahwa sumber daya manusia dan teknologi informasi berpengaruh secara simultan terhadap penerapan SAP basis akrual pada Badan Keuangan Provinsi Gorontalo. 3). Berdasarkan hasil uji regeresi berganda menunjukkan bahwa variabel teknologi informasi berpengaruh positif dan signifikan terhadap penerapan SAP basis akrual, dan variabel sumber daya manusia berpengaruh dan signifikan terhadap penerapan SAP basis akrual. 4). Berdasarkan nilai koefisien determinan atau $R$ square sebesar 0,289 ini menunjukkan bahwa 28,9\% penerapan SAP basis akrual dipengaruhi oleh variabel sumber daya manusia dan teknologi informasi, sedangkan untuk sisanya sebesar $71,1 \%$ dipengaruhi oleh variabel lain yang belum diteliti dalam penelitian ini.

Berdasarkan data penelitian, dilihat dari latar belakang pendidikan pegawai yang dimiliki oleh Badan Keuangan Provinsi Gorontalo dari 60 orang sampel terdapat 30 orang pegawai yang berlatar belakang pendidikan ekonomi dan dari 30 orang tersebut yang berlatar belakang pendidikan ekonomi akutansi ada 17 orang dan sisahnya berlatar belakang Non ekonomi. Sebaiknya agar pemanfaatan sumber daya manusia lebih baik maka disarankan untuk yang pegawai yang berlatar belakang pendidikan ekonomi akuntansi tersebut untuk kualitas sumber dayanya lebih ditingkatkan lagi dalam memahami Standar akuntansi pemerintahan Berbasis Akrual pada Badan Keuangan Provinsi Gorontalo agar dalam proses penerapan SAP basis akrual berjalan dengan baik.

Teknologi informasi pada Badan Keuangan Provinsi Gorontalo sebaiknya diperluas lagi, dalam hal ini agar diperbaharui dari segi jumlah komputer, fasilitas wifi (jaringan), dan sebaiknya untuk sistem/aplikasi SAP agar terus mengikuti atau memperbaharuinya berdasarkan aplikasi versi terbaru setiap tahun, dan lebih baik lagi apabila dalam penerapan SAP memiliki aplikasi tersendiri, sehingga menunjang kesiapan teknologi informasi yang dimiliki oleh Badan Keuangan Provinsi Gorontalo dalam penerapan SAP basis akrual.

\section{DAFTAR PUSTAKA}

Arif Bachtiar, Muchlis, Iskandar. 2002. Akuntansi Pemerintahan, Jakarta : Salemba Empat.

Arikunto, A. 2011. Etika Bisnis Bagi Pelaku Bisnis. Jakarta: Rajawali Pers.

Baswir, Revrisond. 2005. Akuntansi Pemerintahan Indonesia. Jogjakarta : BPFE

Bastian, Indra. 2009. Akuntansi Sektor Publik di Indonesia. Yogyakarta : BPFE

Damanik, 2011. "Faktor-faktor Yang Menjadi Kendala Dalam Penerapan Standar Akuntansi Pemerintahan (SAP) Pada Pemerintah Kota Binjai"

Darise, Nurlan. 2009. Pengelolaan Keuangan Daerah. Jakarta : Penerbit PT. Indeks

Elvis $\mathrm{F}$ Purba, Simanjuntak Parulian, 2011. Metode Penelitian : Universitas HKBP Nommensen, Medan.

Etrin Damayanti. 2012. Analisis Implementasi Basis Akrual pada Laporan Keuangan Pemerintah Kota Bekasi

Fakhrurazi. 2010. Standar Akuntansi Pemerintahan. http://Fakhrurrazypi.wordpress.com/t 
ag/standar-akuntansi-pemerintahan Diakses tanggal 12 Desember 2015.

Hafiz, 2012, Akuntansi Pemerintahan Daerah Berbasis Akrual; Pendekatan Teknis Sesuai PP No. 71/2010, Bandung, Alfabeta.

Halim Abdul, 2008. Akuntansi Keuangan Daerah: Salemba Empat, Jakarta,

IKAPI, A. 2013. Standar Akuntansi Pemerintahan. Bandung: Fokus Media.

Mardiasmo. 2009. Akuntansi Sektor Publik, Yogyakarta : cv andi offset.

Muchtar, A.M. 2002. Audit Sistem Informasi: Pendekatan Terstuktur Teori dan

Noerdiawan D,Iswahyudi,Maulidah,2007, Akuntansi Pemerintahan,Jakarta,

Peraturan Pemerintah Nomor 71 Tahun 2010 Tentang Standar Akuntansi Pemerintah Berbasis Akrual.

Peraturan Menteri Dalam Negeri No. 64 Tahun 2013 Pasal 1 ayat (10) tentang Penerapan Standar Akuntansi Pemerintahan Berbasis Akrual

Praktek Aplikasi Bisnis.Edisi ke-1. Andi Offset, Yogyakarta

Sugiyono. 2008. Metode Penelitian Kuantitatif, Kualitatif dan R\&D. Bandung : Alfabeta.

2009. Metode Penelitian Bisnis. Bandung : Alfabeta.

Sutrisno, E. 2014. Manajemen Sumber Daya Manusia. Jakarta: Kencana.

Tanjung, Abdul Hafiz, 2012. Akuntansi Pemerintahan Daerah Berbasis Akrual. Bandung : ALFABETA.

Undang-Undang Nomor 17 Tahun 2003 Tentang Keuangan Negara.
Williams, B.K. and Sawyer, S.C.et al. 2011. "Using Information Technology: A Practical Introduction to Computers \& Communications. (9th edition)". New York: McGrawHill 